\title{
New investment in international health care graduates
}

A nother \$8.35 million in federal funds to help internationally educated health care professionals join the Canadian workforce is welcome, but those graduates alone will not solve the physician shortage, says the Canadian Medical Association (CMA).

On Mar. 13, Health Minister Rona Ambrose announced that the federal government is giving the Ontario government \$8.2 million over two years to support training programs for internationally educated health professionals and employers. Ottawa is also providing the Medical Council of Canada with $\$ 150000$ over two years to develop orientation materials for graduates undergoing a practiceready assessment.

"With thousands of new

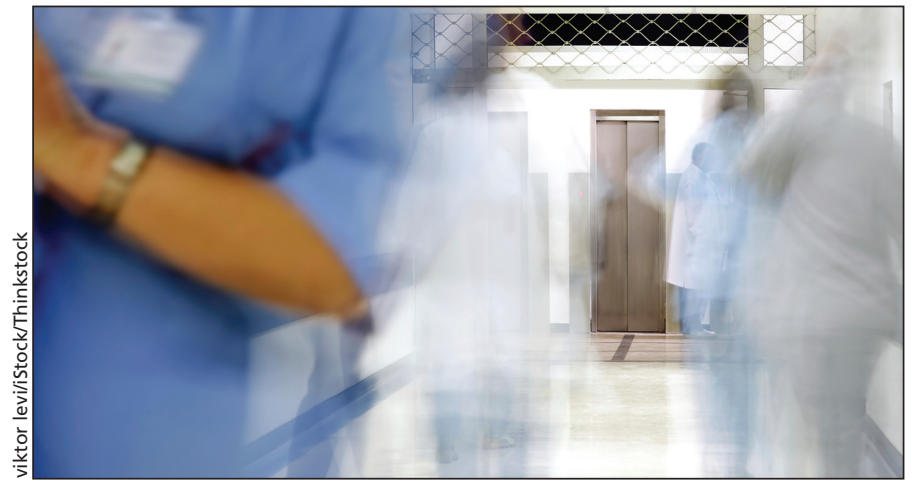

Canada needs more undergraduate and postgraduate slots to solve its physician shortage, says the CMA.
Canadians arriving in Canada every year, we want to ensure that we effectively integrate doctors and nurses into the Canadian health workforce," Ambrose said in a statement.

The bulk of the money goes to HealthForceOntario, a collaboration between Ontario's Ministry of Health and Longterm Care and its Ministry of Training, Colleges and Universities. HealthForceOntario was created to ensure Ontario has the right mix and number of health care professionals. The new federal money will go to three programs:

- a Practice-Ready e-Learning Program for internationally educated health professionals, focused on soft skills, communications and employer expectations

- a Workforce Integration Network program to help managers, supervisors and coworkers integrate international graduates into clinical sites

- an Alternative Career Program to match international graduates with health jobs while they continue to seek licensure.

HealthForceOntario will share the results of these programs with other provinces and territories, Health Canada told CMAJ in a statement. The new initiatives are intended to help bridge the gap between the 4.6 million Canadians who lack a family doctor and the 10000 newcomers to Canada who are trained health care professionals but

Today, Canadian medical schools admit about 3000 students a year, an increase from about 1550 annually in the late 1990s, says Barer. Assuming most graduates stay in Canada, roughly 3000 new doctors will enter practice every year, not counting international graduates, and about 1550 will retire.

"So for the foreseeable future you're going to have many more new physicians moving into the system than you are going to have retirements."

The key to increasing the number of internationally educated medical graduates practising in Canada is opening up more residency spots, says Barer. Allocating those spots differently could also regulate the types of specialties Canada needs, he says.

There has been no national study of Canada's physician

have difficulty getting licensure or jobs.

Close to a quarter of all doctors practising in Canada were educated internationally, and the CMA supports bringing qualified graduates into practice here, the association stated in a news release. But the association does not support actively recruiting doctors from developing countries to solve what it describes as "our physician shortage."

"Canada must strive for greater selfsufficiency in the education and training of physicians," CMA President Dr. Chris Simpson stated. "Serious challenges in health human resources persist."

It's unclear, however, whether a physician shortage looms in Canada as doctors in the baby boom demographic retire, says Morris Barer, a professor at the Centre for Health Services and Policy Research at the University of British Columbia.

"You're never going to have an answer to the question of whether there is a shortage or a surplus at any one time, because there are just too many variables in play," Barer said in an interview from Vancouver. requirements for nearly 40 years, the CMA contends. The association hopes Ottawa will help develop an overarching plan that includes money for infrastructure, human resource planning, immigration policies, health information systems and technology, and mechanisms to repatriate Canadian doctors.

The CMA is lobbying for a Health Human Resource Infrastructure Fund to expand undergraduate and postgraduate slots in Canada's medical schools, so both domestic and international medical school graduates can access postgraduate training, says Dr. Cindy Forbes, CMA's president-elect. There is a precedent: in 1966 the federal government's $\$ 500$ million Health Resources Fund enabled the building of medical schools at Memorial University, University of Sherbrooke, McMaster University and University of Calgary medical schools.

"It is time for the government to play a similar articulated leadership role," Forbes told CMAJ in an email. — Laura Eggertson, Ottawa, Ont. 